Crop Breeding and Applied Biotechnology 13: 107-112, 2013

Brazilian Society of Plant Breeding. Printed in Brazil

\title{
ARTICLE
}

\section{Heritability of stem straightness and genetic correlations in Eucalyptus cladocaly $x$ in the semi-arid region of Chile}

\author{
Felipe Vargas-Reeve ${ }^{1}$, Freddy Mora ${ }^{2 *}$, Sandra Perret ${ }^{3}$ and Carlos Alberto Scapim ${ }^{4}$
}

Received 10 April 2012

Accepted 13 November 2012

\begin{abstract}
The aim of this study was to determine genetic parameters for straightness of the trunk of Eucalyptus cladocalyx, with a view to the selection of straight trees, while keeping the impact on growth minimal. The tests were conducted at two locations in the semi-arid region of Chile, using a randomized block design, with 30 replications and 49 half-sib families. The parameters were estimated by a bi-character model of individual trees, using Bayesian inference by Gibbs algorithm. The heritability for stem straightness was shown to be moderate, with $h^{2}=0.40$ [0.29-0.57]. Heritabilities for diameter and height were moderate: 0.30 [0.24-0.38] and 0.30 [0.22-0.44]. Genetic correlations between straightness and growth were statistically not different from zero. The genotypeenvironment interaction was not significant $(p>0.05)$ for the traits. The moderate degree of genetic control allows significant genetic gains in environments under water stress.
\end{abstract}

Key words: Bayesian inference, Gibbs sampling algorithm, water stress, Eucalyptus.

\section{INTRODUCTION}

The genus Eucalyptus, with over 700 species, is native to Australia and adapted to various ecosystems, from tropical regions with abundant rainfall to semi-arid areas with prolonged dry periods, demonstrating the potential for cultivation under different environmental conditions (Ladiges et al. 2003, Grattapaglia and Kirst 2008). In this sense, Eucalyptus cladocalyx is a species that grows naturally in the semi-arid zone of South Australia, in the regions of Kangaroo Island, Flinders Ranges and Eyre Peninsula (Brooker and Kleinig 1999, Mcdonald et al. 2003), and is adapted to average rainfall levels of 400 to $600 \mathrm{~mm}$ per year (Blakemore 2004, Callister et al. 2008).

A plantation with E. cladocalyx can have multiple productive utilities, e.g., of honey production and timber resources. The wood of sugar gum has extraordinary resistance, durability and high density (Blakemore 2004, Callister et al. 2008). This product is result of the selection of trees with improved growth traits (e.g., straightness), to produce poles for agriculture (Mora et al. 2009, Bush et al. 2011). In this sense, the genetic evaluation plays a key role in breeding for wood quality (Mahmood et al. 2003, Cappa et al. 2010), because the variability within a given population is the basis underlying genetic gains and a result of the expression of each particular genotype and its interaction with the environment. The conservation of the genetic diversity and heterozygosity in allogamous species such as Eucalyptus can maintain the possibility of permanent genetic gains over time (Danusevicius and Lindgren 2002).

The estimation of the individual genetic value is closely linked to the precision degree at which the (co)variance is estimated. In fact, a lower accuracy is directly proportional to a greater deviation from the actual genetic value (Faria et al. 2007). In this context, according to Van-Tassell et al. (1998), an alternative analysis for genetic evaluation would be the Bayesian approach, which is considered accurate to predict the genetic merit. By the Bayesian analysis, results are obtained from the posterior density of the parameters of interest, which is derived from the combination of the information contained in the sample and the a priori prob-

\footnotetext{
Universidad de Concepción, Facultad de Ciencias Forestales, Victoria 631, Barrio Universitario, Concepción, Chile

2 Universidad de Talca, Instituto de Biología Vegetal y Biotecnología, 2 Norte 685, Talca, Chile. *E-mail: fmora@utalca.cl

Instituto Forestal, kilómetro 5, costado aeródromo La Florida, La Serena, Chile

4 Universidade Estadual de Maringá, Departamento de Agronomia, Av. Colombo, 5790, 87.020-900, Maringá, PR, Brazil
} 
ability distribution. The posterior estimates are obtained by means of stochastic simulation algorithms that are used in cases of difficulties with the analysis of the models (VanTassell et al. 1998, SAS 2006).

The purpose of this study was to determine the heritability, genetic correlations, and individual breeding values for stem straightness, height and diameter in E. cladocalyx, using the Bayesian inference as methodology of prediction of genetic parameters.

\section{MATERIAL AND METHODS}

The progeny trials of $E$. cladocalyx were carried out in the administrative region of Coquimbo, in northern Chile, on the farms Hacienda Agrícola Caracas and Comunidad Agrícola Tunga Norte. Caracas ( $31^{\circ} 55^{\prime} 05^{\prime}$ ' S, $71^{\circ} 27^{\prime} 10^{\prime}$ " $\mathrm{W}, 167 \mathrm{~m}$ asl), is a coastal area with humidity of $74-80 \%$, abundant morning cloudiness, rainfall of $201 \mathrm{~mm} \cdot \mathrm{yr}^{-1}$ and temperatures between 12 and $19{ }^{\circ} \mathrm{C}$. On the other hand, in the experiment of Tunga norte ( $31^{\circ} 38>27>>\mathrm{S}, 71^{\circ} 19^{\prime}$ $40^{\prime}$ W, $297 \mathrm{~m}$ asl), mornings are less cloudy and average rainfall $244 \mathrm{~mm} \cdot \mathrm{yr}^{-1}$, with temperatures between 12 and $20{ }^{\circ} \mathrm{C}$. The height of this location is at the limit above which an area is considered intermediate mountainous (over $300 \mathrm{~m}$ asl).

The experiment originally consisted of 2940 trees, planted in June 2001, in a randomized block design with 30 replications and 49 half-sib families. Forty-seven families were provided by CSIRO (Commonwealth Scientific and Industrial Research Organization), Australia (Cané-Retamales et al. 2011). The other two families were obtained from previously established plantations in the region of Coquimbo.

The stem straightness of 9-year-old E. cladocalyx trees was evaluated. This trait was measured on a categorical scale with four levels: 00 - strongly twisted stems, 01 moderate levels of curvature, 02 - slightly curved stems, and 03 - completely straight stems. The diameter at breast height (DBH, measured at a height of $1.3 \mathrm{~m}$ from the stem base) and total tree height were measured in the beginning of December 2010.

The individual trees were genetically evaluated by Bayesian methods, using the program MTGSAM (Multiple-Trait Gibbs Sampler for Animal Models), described by Van-Tassel and Van-Vleck (1996), which allows to generate posterior density distributions of the variance components and of the genetic parameters of the model. For traits of interest, the model of individual trees can include all known family relationships between individuals. In the Bayesian framework, the Gibbs sampling algorithm is used to predict random variables from the conditional probability function of the parameters and the data likelihood function (Bink et al. 2008).

We used a bi-character model to calculate the additive genetic correlations between two different measured traits of the same individual as well as the genetic correlation between two locations, considering the measurements at the two locations as different characters (Cappa et al. 2010). The model can be described as follows:

$$
\left[\begin{array}{l}
Y_{1} \\
Y_{2}
\end{array}\right]=\left[\begin{array}{cc}
X_{1} & 0 \\
0 & X_{2}
\end{array}\right]\left[\begin{array}{l}
\beta_{1} \\
\beta_{2}
\end{array}\right]+\left[\begin{array}{cc}
Z_{1} & 0 \\
0 & Z_{2}
\end{array}\right]\left[\begin{array}{l}
u_{1} \\
u_{2}
\end{array}\right]+\left[\begin{array}{l}
\varepsilon_{1} \\
\varepsilon_{2}
\end{array}\right]
$$

Where $Y_{1}$ and $Y_{2}$ are the vectors of observed responses for each trait (1 and 2); $\boldsymbol{X}_{1}$ and $\boldsymbol{X}_{2}$ represent the design matrices; $\boldsymbol{\beta}_{1}$ and $\boldsymbol{\beta}_{2}$ are the vectors of the parameters of location, block within location and population; $\boldsymbol{Z}_{1}$ and $\boldsymbol{Z}_{\mathbf{2}}$ are the incidence matrices for additive effects; $\boldsymbol{u}_{1}$ and $\boldsymbol{u}_{2}$ the vectors of additive effects and $\varepsilon_{1}$ and $\varepsilon_{2}$ the error vectors. For stem straightness a threshold model proposed by Van-Tassel et al. (1998) was used. The differences between populations were corroborated by confidence intervals of $95 \%$ probability (or credibility intervals, in the Bayesian framework), from the posterior distributions of estimated differences in the population mean using WINBUGS (Bayesian inference Using Gibbs Sampling) (Spiegelhalter et al. 2002). The uniform distribution was considered for the effects of vector $\boldsymbol{\beta}$. The genetic effects were assumed to be normally distributed, whereas the prior distribution of the (co)variance components was recognized as inverted Wishart distribution.

The Markov chains achieved convergence for all parameters using a burn-in of 10000 iterations and a total of 250000 Gibbs sampling rounds. The final size of the Gibbs chain was obtained in steps, every 20 iterations, to ensure the independence between each state, creating a total of 10 000 data per parameter (Wright et al. 2000).

To analyze the Gibbs chains, the autocorrelation test was used based on visual inspection in program $\mathrm{R}$. To test the convergence of the chains, we used the test of Heidelberger and Welch, calculated from the CODA library (Convergence Diagnosis and Output Analysis), in program R.

The narrow-sense heritability was estimated by the following expression:

$$
\mathrm{h}^{2}=\frac{\sigma_{\mathrm{a}}^{2}}{\left(\sigma_{\mathrm{a}}^{2}+\sigma_{\varepsilon}^{2}\right)}
$$

where $\sigma_{\mathrm{a}}^{2}$ is the additive variance and $\sigma_{\varepsilon}^{2}$ the residual variance. The denominator of the equation corresponds to the total phenotypic variance. 
Heritability of stem straightness and genetic correlations in Eucalyptus cladocalyx in the semi-arid region of Chile

The genetic correlations between stem straightness, diameter and height were computed by:

$$
\Gamma=\frac{\sigma_{\mathrm{xy}}}{\sqrt{\left(\sigma_{\mathrm{x}}^{2} \cdot \sigma_{\mathrm{y}}^{2}\right)}}
$$

where $\sigma_{\mathrm{xy}}$ is the additive covariance between two characters ( $\mathrm{x}$ and $\mathrm{y}), \sigma_{\mathrm{x}}^{2}$ and $\sigma_{\mathrm{y}}^{2}$ corresponds to the additive variances for the traits $\mathrm{x}$ and $\mathrm{y}$, respectively. The previous relationship is also valid for the estimation of the additive genetic correlation between environments.

\section{RESULTS AND DISCUSSION}

In the analyses, significant differences were found between populations for the traits stem straightness and growth (Table 1). The best stem straightness was found in a population from Illapel, Chile (index 2.5); followed by Wirrabara (2.24) and Remarkable (2.17). The stem straightness of population Marble Range was poorest, with (0.29). Wirrabara and Flinders Chase had the best height growth, and Wirrabara the best diameter growth as well. This variability is consistent with that reported by Mora et al. (2007), Bush et al. (2011), Contreras-Soto et al. (2011) and Cane-Retamales et al. (2011). The existence of variability in the study populations is an important aspect to maintain genetic gains in the long term, based on an adequate level of genetic diversity in the parentage analysis and a suitable size of the breeding population (Rosvall and Mullin 2003). This variability occurs although the populations of E. cladocalyx are restricted to three semiarid regions of southern Australia, which are: Penynsula Eyre (average rainfall $\left.445.1 \mathrm{~mm} \mathrm{yr}^{-1}\right)$, Kangaroo Island (637.9 $\left.\mathrm{mm} \mathrm{yr}^{-1}\right)$ and Flinders Ranges (249.7 $\mathrm{mm} \mathrm{yr}^{-1}$ ) (McDonald et al. 2003, Brooker and Kleinig 1999). In addition, high inbreeding levels have a strong effect on the population genetic structure, since inbreeding can reduce genetic variation and gene flow, increasing the interpopulational differentiation (Hartl 2000, McDonald et al. 2003).
Table 1. Average response of populations (stem straightness scored 0-3; Height measured in meters, diameter at breast height (DBH) measured in centimeters) of Eucalyptus cladocalyx in northern Chile

\begin{tabular}{lccc}
\hline Origin & $\begin{array}{c}\text { Straightness* } \\
(\mathrm{MS})\end{array}$ & $\begin{array}{c}\text { Height* } \\
(\mathrm{m})\end{array}$ & $\begin{array}{c}\text { DBH* } \\
(\mathrm{cm})\end{array}$ \\
\hline Illapel & $2.48 \mathrm{a}$ & $5.84 \mathrm{~b}$ & $6.60 \mathrm{bc}$ \\
Wirrabara & $2.24 \mathrm{~b}$ & $6.44 \mathrm{a}$ & $7.42 \mathrm{a}$ \\
Remarkable & $2.17 \mathrm{~b}$ & $5.82 \mathrm{~b}$ & $6.58 \mathrm{c}$ \\
Flinders Chase & $1.97 \mathrm{c}$ & $6.42 \mathrm{a}$ & $6.86 \mathrm{~b}$ \\
Cowell & $0.64 \mathrm{~d}$ & $3.67 \mathrm{~d}$ & $3.22 \mathrm{e}$ \\
Marble Range & $0.29 \mathrm{e}$ & $3.90 \mathrm{c}$ & $4.21 \mathrm{~d}$ \\
\hline
\end{tabular}

* Means not followed by the same letter in the column differ significantly according to the Bayesian confidence interval (probability $=95 \%$ ). DBH: diameter at breast height. MS: multinomial scale, character stem straightness, scored 0-3 (00 - strongly twisted stem, 01 - moderate level of curvature, 02 - slightly curved stem, and 03 completely straight stem).

The Heidelberger and Welch test corroborated the convergence of Gibbs chains for all parameters in the Bayesian model. Table 2 shows the point estimates characterizing the marginal posterior distributions generated by the Gibbs algorithm (mean, mode, and median) for stem straightness. The value for the inheritance mode of stem straightness was similar at the locations: 0.44 and 0.38 with Bayesian confidence intervals $0.33-0.65$ and $0.28-0.58$, respectively, for Agrícola Caracas and Tunga Norte. For growth traits, the heritability values were estimated at 0.30 , with confidence intervals of 0.24-0.38 and 0.22-0.44, respectively for diameter and height growth (average of locations). The slight differences between mean, mode and median showed a lack of asymmetry in the posterior distributions of heritability. These data are in agreement with findings of Harwood et al. (2007), who reported moderate heritability for height and diameter growth of E. cladocalyx trees, with values of 0.25 and 0.21 , respectively. Mora et al. (2009) evaluated the tree height and basal diameter of 5- year-old E. cladocalyx trees in a pre-analysis of the experiment of Tunga Norte, evaluating 39 half-sib families. The growth traits were moderately heritable with posterior means (Bayesian confidence intervals $)$ of $\mathrm{h}^{2}=0.28(0.21-0.37)$ and $\mathrm{h}^{2}=0.14(0.04-0.28)$

Table 2. Estimates of variance components and posterior heritability for stem straightness, diameter and height, evaluated in 49 half-sib families of Eucalyptus cladocalyx, in Chile

\begin{tabular}{lccccccc}
\hline Origin & Parameter & Mode & Mean & Median & SD & \multicolumn{2}{c}{ BCI (\%) } \\
\hline \multirow{3}{*}{ Caracas } & $\sigma_{a}^{2}$ & 0.18 & 0.19 & 0.19 & 0.05 & 0.13 & 0.28 \\
& $\sigma_{e}^{2}$ & 0.23 & 0.22 & 0.22 & 0.04 & 0.15 & 0.28 \\
\hline \multirow{3}{*}{ Tunga } & $h^{2}$ & 0.44 & 0.46 & 0.46 & 0.10 & 0.33 & 0.65 \\
Norte & $\sigma_{a}^{2}$ & 0.13 & 0.14 & 0.14 & 0.04 & 0.09 & 0.21 \\
& $\sigma_{e}^{2}$ & 0.21 & 0.20 & 0.21 & 0.03 & 0.15 & 0.25 \\
\hline
\end{tabular}

SD: Standard deviation; $\sigma_{a}^{2}$ : Additive genetic variance; $\sigma_{e}^{2}$ : Residual variance; $h^{2}$ : Heritability. BCI: Bayesian confidence interval or credibility interval. 
for height and diameter growth, respectively. The genetic control of the narrow-sense heritability of these traits in different Eucalyptus species has generally been described as low to moderate (Ginwal et al. 2004, Volker et al. 2008, Hamilton et al. 2009).

Callister et al. (2008) estimated genetic parameters of E. cladocalyx for several traits, including stem straightness, which is one of the few studies addressing this character. The results, evaluating three trials in Australia, showed different values of narrow-sense heritability (0.16-0.50). In another study on the genetic control of stem straightness in E. cladocalyx, developed in South Australia with 28-month-old trees, Harwood et al. (2007) found a moderate heritability value of $(0.21)$. The results of these studies corroborate the moderate heritability detected in this study. In other species of the genus Eucalyptus, the heritability of stem straightness ranged from moderate to relatively low. For example, Henson et al. (2008) found a heritability of 0.41 for E. longirostrata and Mahmood et al. (2003) found a mean value of 0.15 for $E$. camaldulensis. Mwase et al. (2008) assumed that low heritability values could be related to trees from breeding programs characterized by intense selection in the initial stages, leading to a considerable decrease in variability. However, most studies agree that straightness is a trait with moderate genetic control (Marcó and White 2002, Arnold et al. 2004, Hamilton and Potts 2008). The moderate heritability estimate for stem straightness is evidence of a significant potential for breeding for this trait. This result is significant, considering the limitations from the standpoint of the forestry industry in the region.

The posterior mode of the additive genetic correlation between stem straightness and diameter was 0.19 with an interval of -0.04-0.37. In the case of genetic correlation of stem straightness with height growth, the estimated value was also low $(\mathrm{r}=0.10)$ with an interval of $-0.16-0.35$ (Table $3)$. The genetic correlation of the growth traits evaluated with the degree of stem straightness was low, with values not significantly different from zero, according to the Bayesian confidence intervals $(\mathrm{p}=95 \%)$. These results disagree with the high genetic correlation between the growth traits $(\mathrm{r}=0.81)$, with an interval of $0.71-0.87$, statistically different from zero. The genetic value of individual trees was plotted against the two characters (Figure 1). The genetic correlation between calculated straightness and growth traits were not statistically different from zero, according to the Bayesian intervals ( $\mathrm{P}=95 \%)$. Therefore, the selection of trees focused on straightness alone would obtain no genetic progress for traits related to the tree diameter and height. There are conflicting studies on the impact the trait straightness can have on growth. For example, Cappa et al. (2010) found non-significant genetic correlations for growth and straightness of Eucalyptus viminalis trees in
Table 3. Posterior estimates of the genetic correlations between stem straightness, height and diameter in 49 half-sib families of Eucalyptus cladocalyx in northern Chile

\begin{tabular}{lccc}
\hline \multirow{2}{*}{ Parameter } & \multicolumn{3}{c}{ Genetic correlation } \\
\cline { 2 - 4 } & RT-Diameter & Height-Diameter & SS-Height \\
\hline Mode & 0.19 & 0.81 & 0.10 \\
Mean & 0.17 & 0.80 & 0.10 \\
Median & 0.17 & 0.80 & 0.10 \\
Standard deviation & 0.12 & 0.05 & 0.15 \\
BCI (\%) & & & \\
2.5 & -0.04 & 0.71 & -0.16 \\
97.5 & 0.37 & 0.87 & 0.35 \\
\hline
\end{tabular}

SS: Stem straightness; BCI: Bayesian confidence interval or credibility interval
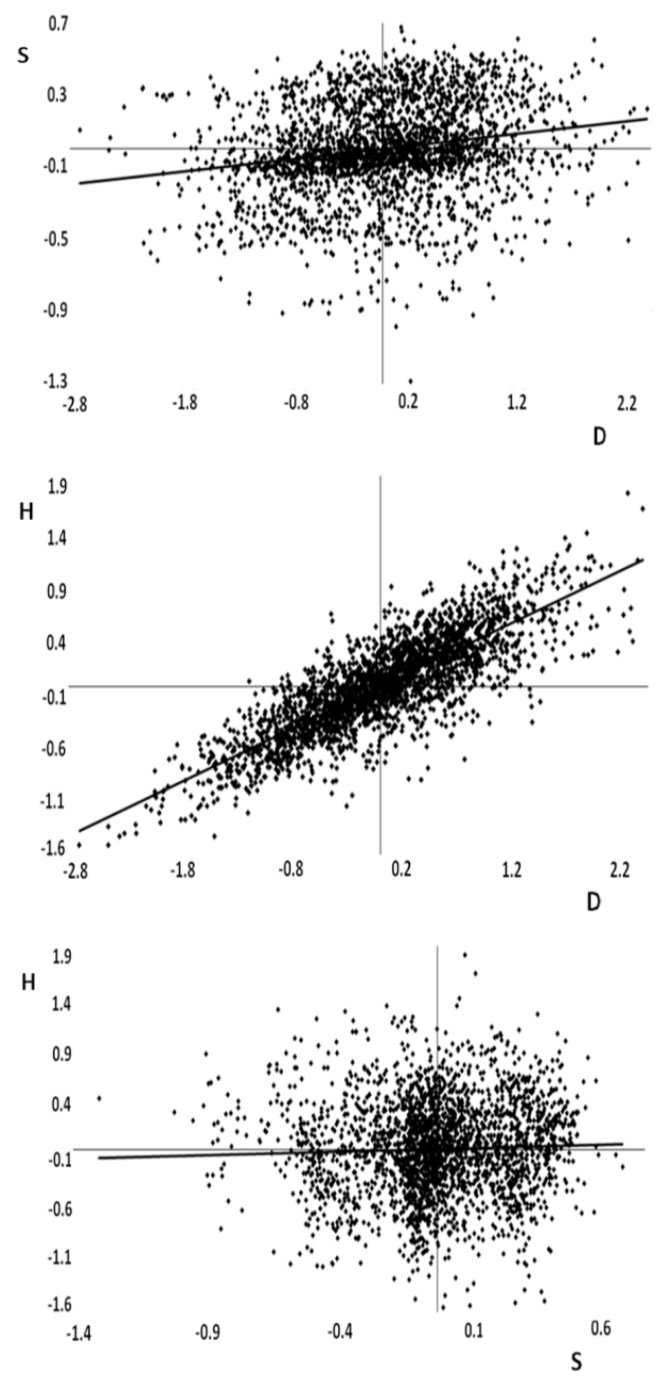

Figure 1. Genetic values of Eucalyptus cladocalyx trees for growth traits (H: height, D: diameter) and stem straightness (S); lines indicate the correlation between traits. 

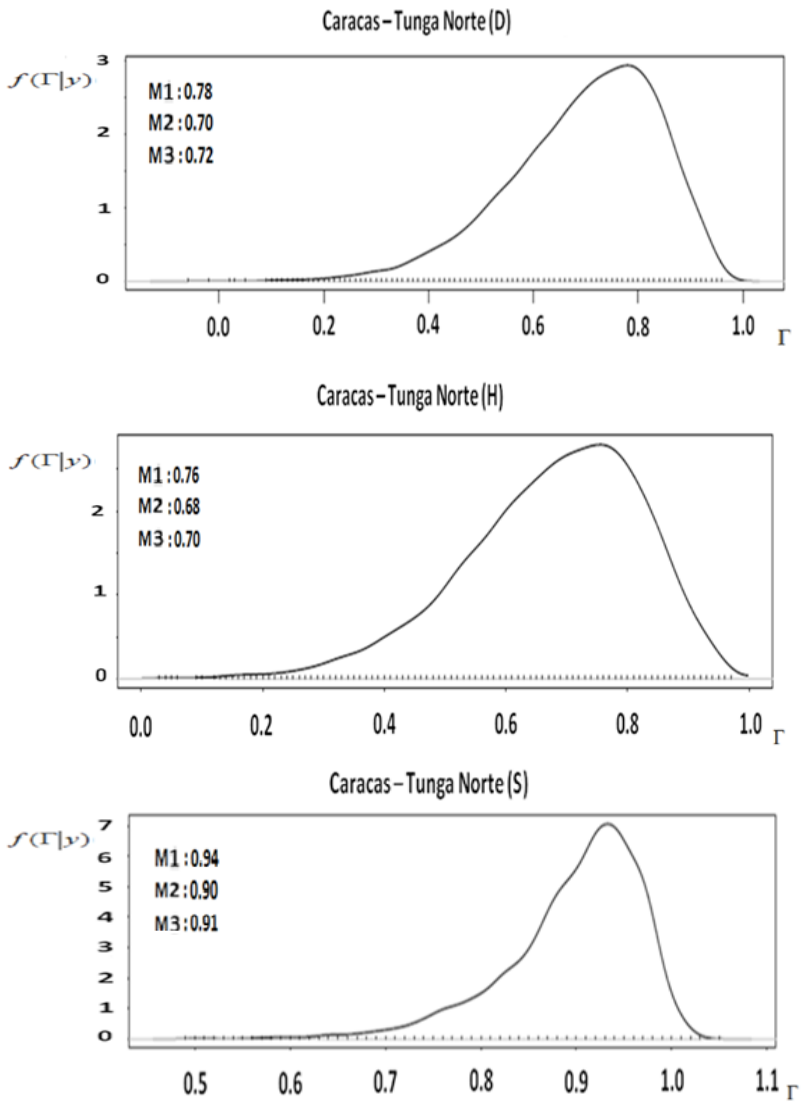

Figure 2. Marginal posterior distributions of genetic correlations $(\mathrm{G})$ between sites, for Eucalyptus cladocalyx trees evaluated in Chile (M1: mode; M2: mean; M3: median, D: diameter, H: height, S: straightness of the stem).

two trials in Argentina; the correlation ranged from -0.09 to -0.02 , confirming the null relationship between the traits. But at another location, Cappa et al. (2010) found a high, positive and significant genetic correlation (0.67 and 0.70 ). Callister et al. (2008) reported positive genetic correlations between straightness and growth, although most of the estimated values were statistically not different from zero, with high standard errors.
The marginal posterior distributions of the estimated genetic correlation between environments are shown in Figure 2. The values of genetic correlation between locations were high and statistically different from zero, according to the Bayesian confidence intervals $(\mathrm{p}=95 \%)$, indicating no genotype-environment interaction; because the values of genetic correlation were positive and relatively high, in other words, the best-performing trees of one location could maintain this superiority at another. The high correlations computed by the bi-character model indicated relative stability for straightness and growth at the experimental locations, evidencing the low level of genotype-environment interaction. This result coincides with that found by Callister et al. (2008), for E. cladocalyx. Although the trials studied cover $480 \mathrm{~km}$, with differences in water availability and soil texture, Callister et al. (2008) found high Type-B genetic correlations for growth and stem straightness, indicating a lack of interaction for these traits at the three locations in the western part of Australia.

\section{CONCLUSION}

The Bayesian inference proved to be a suitable option to estimate the (co)variance components and genetic parameters, indicating that stem straightness and growth are determined by a moderate additive genetic control.

At the experimental locations, the genotype-environment interaction for stem growth and straightness would not be a problem in the individual selection.

The results indicated a high potential for improvement for growth traits and stem straightness, although the zero genetic correlation between both characters could hamper the achievement of straight trees with higher growth.

\section{ACKNOWLEDGEMENTS}

The authors are indebted to Fondecyt (Project No. 11090129) for the financial support of this study.

\title{
Herdabilidade da retidão do tronco e correlações genéticas em Eucalyptus cladocalyx no semi-árido do Chile
}

\begin{abstract}
Resumo - O objetivo deste trabalho foi determinar parâmetros genéticos para retidão do tronco em Eucalyptus cladocalyx, com o intuito de selecionar árvores retas, porém com o mínimo impacto sobre o crescimento. Os ensaios foram conduzidos em dois locais no semi-árido do Chile em delineamento de blocos ao acaso com 49 famílias de meios-irmãos. Os parâmetros foram estimados com modelo bicaráter de árvores individuais, usando inferência Bayesiana via algoritmo de Gibbs. A retidão do tronco mostrou ser moderadamente herdável com $h^{2}=0,40$ [0,29-0,57]. Herdabilidades para diâmetro e altura foram de 0,30 [0,24-0,38] e 0,30 [0,22-0,44]. Correlações genéticas entre retidão e crescimento não diferem estatisticamente de zero. A interação genótipo-ambiente não foi significativa $(p>0,05)$ para as características. O moderado grau de controle genético permitirá a obtenção de importantes ganhos genéticos em ambientes com déficit hídrico.
\end{abstract}

Palavras-chave: Inferência bayesiana, algoritmo de Gibbs, déficit hídrico, eucalipto. 


\section{REFERENCES}

Arnold RJ, Johnson IG and Owen JV (2004) Genetic variation in growth, stem straightness and wood properties in Eucalyptus dunnii trials in Northern New South Wales. Forest Genetics 11: 1-12.

Bink MCAM, Boer MP, Ter Braak CJF, Cansen J, Voorrips, RE and Van de Weg WE (2008) Bayesian analysis of complex traits in pedigreed plant populations. Euphytica 161: 85-96.

Blakemore P (2004) Density and shrinkage of four low-rainfall plantationgrown eucalypts. Australian Forestry 67: 152-155.

Brooker MIH and Kleinig DA (1999) Field guide to eucalypts. Bloomings Books, Australia, 326p.

Bush D, McCarthy K and Meder R (2011) Genetic variation of natural durability traits in Eucalyptus cladocalyx (sugar gum). Annals of Forest Science 68: 1057-1066.

Callister A, Bush DJ, Collins S and Davis W (2008) Prospects for genetic improvement of Eucalyptus cladocalyx in Western Australia. New Zealand Journal of Forestry Science 38: 211-226.

Cané-Retamales C, Mora F, Vargas-Reeve F, Perret S and Contreras-Soto R (2011) Bayesian threshold analysis of breeding values, genetic correlation and heritability of flowering intensity in Eucalyptus cladocalyx under arid conditions. Euphytica 178: 177-183.

Cappa EP, Pathauer PS and López GA (2010) Provenance variation and genetic parameters of Eucalyptus viminalis in Argentina. Tree Genetics and Genomes 6: 981-994.

Contreras-Soto R, Mora F, Perret S, Vargas-Reeve F and Cané-Retamales C (2011) Predicción bayesiana del comportamiento poblacional de Eucalyptus cladocalyx para características binarias de componentes de florecimiento y supervivencia en zonas áridas de Chile. Interciencia 36: 644-649.

Danusevicius D and Lindgren D (2002) Two-stage selection strategies in tree breeding considering gain, diversity, time and cost. Forest Genetics 9: 147-159.

Faria CU, Magnabosco CU, Reyes A, Lôbo RB, Bezerra LAF and Sainz RD (2007) Bayesian inference in a quantitative genetic study of growth traits in Nelore cattle (Bos indicus). Genetics and Molecular Biology 30: 545-551.

Ginwal HS, Kumar P, Sharma VK, Mandal AK and Harwood CE (2004) Genetic variability and early growth performance of Eucalyptus tereticornis $\mathrm{Sm}$. in provenance cum progeny trials in India. Silvae Genetica 53: $148-153.0$

Grattapaglia D and Kirst M (2008) Eucalyptus applied genomics: from gene sequences to breeding tools. New Phytologist 179: 911-929.

Hamilton MG and Potts BM (2008) Review of Eucalyptus nitens genetic parameters. New Zealand Journal of Forestry Science 38: 102-119.

Hamilton M, Raymond C, Harwood C and Potts B (2009) Genetic variation in Eucalyptus nitens pulpwood and wood shrinkage traits. Tree Genetics \& Genomes 5: 307-316.

Hartl DL (2000) A primer of population genetics. Sinauer Associates, Massachusetts, 180p.

Harwood CE, Bush DJ, Butcher T, Bird R, Henson ML, Lott R and Shaw S (2007) Achievements in forest tree genetic improvement in Australia and New Zealand. 4: Tree improvement for low-rainfall farm forestry. Australian Forestry 70: 23-27.
Henson M, Smith HJ and Boyton S (2008) Eucalyptus longirostrata: A potential species for Australia's tougher sites New Zealand Journal of Forestry Science 38: 227-238.

Ladiges PY, Udovicic F and Nelson G (2003) Australian biogeographical connections and the phylogeny of large genera in the plant family Myrtaceae. Journal of Biogeography 30: 989-998.

Mahmood K, Marcar NE, Naqvi MH, Arnold RJ, Crawford DF, Iqbal S and Aken KM (2003) Genetic variation in Eucalyptus camaldulensis Dehnh. for growth and stem straightness in a provenance-family trial on salt land in Pakistan. Forest Ecology Management 176: 405-416.

Marcó M and White T (2002) Genetic parameter estimates and genetic gains for Eucalyptus grandis and E. dunnii in Argentina. Forest Genetics 9: 205-215.

McDonald MW, Rawllings M, Butcher PA and Bell JC (2003) Regional divergence and inbreeding in Eucalyptus cladocalyx (Myrtaceae). Australian Journal of Botany 51: 393-403.

Mora F, Perret S, Scapim CA, Martins EN and Molina MP (2007) Source-dependent blooming variability of Eucalyptus cladocalyx in the Region of Coquimbo, Chile. Ciencia e Investigación Agraria 34: 99-106.

Mora F, Gleadow R, Perret S and Scapim CA (2009) Genetic variation for early flowering, survival and growth in sugar gum (Eucalyptus cladocalyx F. Muell) in southern Atacama Desert. Euphytica 169: 335-344.

Mwase WF, Savill PS and Hemery G (2008) Genetic parameter estimates for growth and form traits in common ash (Fraxinus excelsior $\mathrm{L}$.) in a breeding seedling orchard at Little Wittenham in England. New Forests 36: 225-238.

Rosvall O and Mullin TJ (2003) Positive assortative mating with selection restrictions on group coancestry enhances gain while conserving genetic diversity in long-term forest tree breeding. Theoretical and Applied Genetics 107: 629-642.

SAS (2006) Preliminary capabilities for bayesian analysis in SAS/STAT R Software. SAS Institute Inc, Cary.

Spiegelhalter DJ, Best NG, Carlin BP and Van der Linde A(2002) Bayesian measures of model complexity and fit (with discussion). Journal of the Royal Statistical Society 64: 583-639.

Van-Tassell CP and Van-Vleck LD (1996) Multiple-trait Gibbs sampler for animal models: flexible programs for Bayesian and likelihoodbased (co)variance component inference. Journal of Animal Science 74: $2586-2597$

Van-Tassell CP, Van-Vleck LD and Gregory KE (1998) Bayesian analysis of twinning and ovulation rates using a multiple trait threshold model and Gibbs sampling. Journal of Animal Science 76: 2048-2061.

Volker PW, Potts BM and Borralho NMG (2008) Genetic parameters of intra- and inter-specific hybrids of Eucalyptus globulus and E. nitens. Tree Genetics \& Genomes 4: 445-460.

Wright DR, Stern HS and Berger PJ (2000) Comparing traditional and Bayesian analyses of selection experiments in animal breeding. Journal of Agricultural, Biological and Environmental Statistics 5: $240-256$. 